\title{
Corrigendum: Updating the Vibrio clades defined by multilocus sequence phylogeny: proposal of eight new clades, and the description of Vibrio tritonius sp. nov.
}

\author{
Tomoo Sawabe ${ }^{1}$, Yoshitoshi Ogura ${ }^{2}$, Yuta Matsumura ${ }^{1}$, Gao Feng $^{1}$, A. K. M. Rohul Amin ${ }^{1}$, \\ Sayaka Mino ${ }^{1}$, Satoshi Nakagawa ${ }^{1}$, Toko Sawabe ${ }^{3}$, Ramesh Kumar', Yohei Fukui ${ }^{5}$, \\ Masataka Satomi ${ }^{5}$, Ryoji Matsushima ${ }^{5}$, Fabiano L. Thompson ${ }^{6}$, Bruno Gomez Gil', \\ Richard Christen $^{8,9}$, Fumito Maruyama ${ }^{10}$, Ken Kurokawa ${ }^{11}$ and Tetsuya Hayashi ${ }^{2}$ \\ ${ }^{1}$ Laboratory of Microbiology, Faculty of Fisheries Sciences, Hokkaido University, Hakodate, Japan \\ 2 Division of Genomics and Bioenvironmental Science, Frontier Science Research Center, University of Miyazaki, Miyazaki, Japan \\ ${ }^{3}$ Department of Food and Nutrition, Hakodate Junior College, Hakodate, Japan \\ ${ }^{4}$ National Institute for Interdisciplinary Science and Technology (CSIR), Kerala, India \\ ${ }^{5}$ National Research Institute of Fisheries Science, Fisheries Research Agency, Yokohama, Japan \\ ${ }^{6}$ Department of Genetics, Center of Health Sciences, Federal University of Rio de Janeiro (UFRS), Rio de Janeiro, Brazil \\ 7 A.C. Unidad Mazatlán, CIAD, Mazatlán, México \\ ${ }^{8}$ CNRS UMR 7138, Systématique-Adaptation-Evolution, Nice, France \\ ${ }^{9}$ Systématique-Adaptation-Evolution, Université de Nice-Sophia Antipolis, Nice, France \\ ${ }^{10}$ Graduate School of Medical and Dental Sciences, Tokyo Medical and Dental University, Tokyo, Japan \\ "Earth-Life Science Institute, Tokyo Institute of Technology, Tokyo, Japan \\ *Correspondence: sawabe@fish.hokudai.ac.jp
}

Edited and reviewed by:

Jonathan P. Zehr, University of California, Santa Cruz, USA

Keywords: vibrios, Vibrionaceae, multilocus sequence analysis, evolution, housekeeping protein gene, Vibrio tritonius

A corrigendum on

Updating the Vibrio clades defined by multilocus sequence phylogeny: proposal of eight new clades, and the description of Vibrio tritonius sp. nov.

by Sawabe T, Ogura Y, Matsumura Y, Feng $G$, Amin AR, Mino $S$, Nakagawa $S$, Sawabe T, Kumar R, Fukui Y, Satomi M, Matsushima R, Thompson FL, Gomez-Gil $B$, Christen R, Maruyama F, Kurokawa K and Hayashi T. (2013) Front Microbiol. 4:414. doi: 10.3389/fmicb.2013.00414

Strain numbers of Vibrio tritonius described on pages 3 and 10 were incorrect.

Correct strain numbers are;

JCM $16456^{\mathrm{T}}=\mathrm{LMG} 25401^{\mathrm{T}}=\mathrm{AM} 2^{\mathrm{T}}$,

JCM 16457=LMG 25404=MA35,

JCM 16458=LMG 25403=MA17, and

JCM 16459=LMG 25402=MA12.

Corrected description is follows;

Description of Vibrio tritonius sp. nov. Etymology of the newly describing Vibrio species was provided here: Vibrio tritonius (tri.to'ni.us. L. masc. adj. tritonius, named after Triton (a sea-god, son of Neptune and the nymph Salacia, referring to the habitat of the bacteria).
Major phenotypic features of $V$. tritonius sp. nov. are shown in Table 3. The four sea hare strains have the major phenotypic features of the genus Vibrio (except for no growth on TCBS and gas production). These strains required salt for their growth, and they were motile, fermentative, and oxidase positive. Apparent catalase activity was not observed. The four strains of $V$. tritonius sp. nov. were phenotypically most similar to $V$. porteresiae, but they differed from $V$. porteresiae in four traits (catalase production, and the assimilation of D-mannose, $\gamma$-aminobutyrate, and pyruvate), out of 62 tested traits (Table 3). The four $V$. tritonius strains were sensitive to the vibrio-static agent $\mathrm{O} / 129(150 \mu \mathrm{g})$. Positive assimilation of glucose, mannitol, gluconate, glucuronate, and xylose indicated the presence of three major carbohydrate metabolic pathways, the Embden-Meyerhof, Entner-Doudoroff, and pentose-phosphate pathways, in V. tritonius sp. nov. Presence of the gene set for those three central metabolic pathways of carbohydrates was supported by our preliminary WGS analysis of $V$. tritonius JCM $16456^{\mathrm{T}}$ (data not shown). Phenotypic traits differentiating $V$. tritonius sp. nov. from $V$. aerogenes, which shows a gas production phenotype, included nitrate reduction, amylase production, and arginine dihydrolase activity. Inability to grow on TCBS was a common trait of $V$. tritonius sp. nov. and $V$. porteresiae (Table 3).

The other phenotypic traits were also described below. No swarming cells were observed. Gas production from glucose and mannitol occurred. Cells are curved rods, with rounded ends, are $0.7-0.9 \mu \mathrm{m}$ in diameter and $2.6-2.7 \mu \mathrm{m}$ in length when the organism is grown on ZoBell $2216 \mathrm{E}$ medium; the cells occur singly on the agar. No endospores or capsules are formed. Colonies on ZoBell 2216E agar medium are beige, circular, and smooth and convex with an entire edge. Sodium ions are essential for growth. The bacterium can grow in presence of $0.5 \%-6 \% \mathrm{NaCl}$. The bacterium is a mesophilic chemoorganotroph which grows at temperatures between 15 and $40^{\circ} \mathrm{C}$. Optimal growth is observed from 25 to $30^{\circ} \mathrm{C}$. Growth occurs from $\mathrm{pH}$ 4.5 to $\mathrm{pH}$ 9, and optimal growth is at $\mathrm{pH}$ 7.5-8.0. No growth occurs at $45^{\circ} \mathrm{C}$. The bacterium is positive for acid production from glucose and mannitol; for 
nitrate reduction, acetoin production, and hydrolysis of gelatin, DNA, and casein. The bacterium also can assimilate $\mathrm{N}$-acetylD-glucosamine, cellobiose, D-fructose, maltose, D-mannitol, D-galactose, lactose, L-glutamate, L-proline, acetate, citrate, fumarate, DL-malate, pyruvate, and succinate. The bacterium is negative for catalase; indole production; arginine dihydrolase, lysine decarboxylase, ornithine decarboxylase, luminescence, and pigmentation; the requirement of organic growth factors; hydrolysis of agar, alginate, starch, and Tween 80; and assimilation of D-glucosamine, D-sorbitol, aconitate, $\alpha$-ketoglutarate, L-tyrosine, meso-erythritol, trehalose, putrescine, propionate, and D-glucosamine. The $\mathrm{G}+\mathrm{C}$ content of DNA is $44.2-45.5 \mathrm{~mol} \%$. The type strain is JCM $16456^{\mathrm{T}}=\mathrm{LMG}$ $25401^{\mathrm{T}}=\mathrm{AM} 2^{\mathrm{T}}$.

Conflict of Interest Statement: The authors declare that the research was conducted in the absence of any commercial or financial relationships that could be construed as a potential conflict of interest.

Received: 16 October 2014; accepted: 16 October 2014; published online: 04 November 2014.

Citation: Sawabe T, Ogura Y, Matsumura Y, Feng G, Amin AKMR, Mino S, Nakagawa S, Sawabe T, Kumar R, Fukui Y, Satomi M, Matsushima R, Thompson FL, Gomez Gil B, Christen R, Maruyama F, Kurokawa
$K$ and Hayashi $T$ (2014) Corrigendum: Updating the Vibrio clades defined by multilocus sequence phylogeny: proposal of eight new clades, and the description of Vibrio tritonius sp. nov.. Front. Microbiol. 5:583. doi: 10.3389/fmicb.2014.00583

This article was submitted to Aquatic Microbiology, a section of the journal Frontiers in Microbiology.

Copyright () 2014 Sawabe, Ogura, Matsumura, Feng, Amin, Mino, Nakagawa, Sawabe, Kumar, Fukui, Satomi, Matsushima, Thompson, Gomez Gil, Christen, Maruyama, Kurokawa and Hayashi. This is an openaccess article distributed under the terms of the Creative Commons Attribution License (CC BY). The use, distribution or reproduction in other forums is permitted, provided the original author(s) or licensor are credited and that the original publication in this journal is cited, in accordance with accepted academic practice. No use, distribution or reproduction is permitted which does not comply with these terms. 